\title{
PŘEKONÁVÁNÍ DUALISMU ŽIVOTA A UMĚNÍ VE FILOSOFII JOHNA DEWEYHO A A. N. WHITEHEADA
}

\author{
ONDŘEJ DADEJÍK \\ Katedra estetiky, Filozofická fakulta, univerzita Karlova \\ E-mail: ondrej.dadejik@ff.cuni.cz \\ Ústav věd o umění a kultuře, Filozofická fakulta, Jihočeská univerzita v českých Budějovicích \\ E-mail: odadejik@ff.jcu.cz
}

\section{ABSTRACT \\ The Overcoming of the Dualism between Art and Life in the Philosophy of John Dewey and Alfred North Whitehead}

In this essay the author argues that there is a close compatibility between John Dewey's social philosophy of art and Alfred North Whitehead's thinking about the relationship between art and life. First, the author outlines the opposition between isolationism and contextualism as two main tendencies in the field of aesthetic theory. He draws on Melvin Rader's explanation of the chief difference between the two: an isolationist theory insists that art is distinct or even separate from the rest of life, whereas a contextualist theory maintains the integrality of art and life. The author then argues that both tendencies are implausible if considered separately, and that - despite the manifest conflict between these tendencies - both Dewey and Whitehead were able to use them to good purpose in their theories. In the second part of the essay, the author points out the similarities between Dewey's and Whitehead's ideas about the rootedness of art in everyday life, revealing the usually not so apparent contextualist, or social, side of Whitehead's conception of art. Finally, in the third part, the author argues that we can usefully trace these similarities and convergences to more fundamental parts of the thinking of both philosophers, especially to their critiques of the dualisms inherent in the constitution of modern thought in general.

Keywords: aesthetic experience; dualism; contextualism; J. Dewey; A. N. Whitehead

\section{Úvod}

Jedním ze schémat, na jejichž pozadí lze porozumět konvergenci, ale zároveň i rozdílům mezi chápáním povahy a smyslu uměleckého tvoření a vnímání uměleckých děl u Alfreda Northe Whiteheada a Johna Deweyho, je rozlišení mezi estetickým kontextualismem a izolacionismem. ${ }^{1}$ Objasněme nejprve, co tyto na první pohled složité termíny ve vztahu k umění a estetické zkušenosti znamenají a v čem nám mohou být při výkladu estetických koncepcí obou filosofů prospěšné.

Izolacionismem míníme ve smyslu rozlišení Melvina Radera takové pojetí, podle něhož je umění odlišné a oddělené od zbytku života. Podle takového pojetí není umění

1 Konflikt těchto dvou vzájemně neoddělitelných komplementárních tendencí, stejně jako možnosti jeho řešení, nastiňuje již Melvin Rader ve studii „Isolationist and Contextualist Esthetics: Conflict and Resolution". Viz M. Rader, Isolationist and Contextualist Esthetics: Conflict and Resolution, The Journal of Philosophy, roč. 44, 1947, č. 15, s. 393-407. 
pouze rozpoznatelnou oblastí určité produkce artefaktů mezi jinými, nýbrž je jako určitá oblast definováno skrze protiklad vioči tomu, co je běžné, obyčejné, každodenní. Obzvláště moderní umění konce 19. a začátku minulého století se ve svých programatických tezích mnohým zdálo potvrzovat představu o umění jako sféře, která se vzdaluje, či dokonce záměrně odcizuje běžnému životu. Řečeno slovy Josého Ortegy y Gasseta z 20. let minulého století, umění ve své podstatě usiluje o to být „dehumanizované“, tzn. brání se rozostřování hranice mezi životem a uměním, snaží se očistit se od mísení obou těchto oblastí. Moderní umělec se podle Ortegy y Gasseta oproštuje od jakéhokoli aspektu žité reality. Předpokladem skutečné umělecké tvorby, neparazitující na doslovnosti všedně sdílených a sdělitelných obsahů, by mělo být „spálení a potopení všech mostů a lodí, kterými bychom se dostali do našeho žitého světa".2

Přirozenou protiváhou výše uvedené tendence je estetický kontextualismus, a to velmi často v reakci na př́liš vypjaté verze estetického izolacionismu a jejich důsledky. Kontextualismus obhajuje kontinuitu mezi uměním a životem. Do této kategorie spadají pojetí kladoucí důraz na předpoklad, že umění tematizuje a intenzifikuje prožití určité živé kvality, která prostupuje náš každodenní život a není výsadou umělecké tvorby. ${ }^{3}$ Pro kontextualistickou teorii je společnost bezvýhradně akceptující bariéru mezi uměním a běžným životem společností ve svých základech narušenou, nebot samozřejmé přijetí dualismu mezi uměním a běžným životem vede $\mathrm{k}$ přijetí života, jenž je určité, životně důležité hodnoty zbaven. Ve společnosti, která odmítá uvažovat o skutečnostech každodenního, mimouměleckého života jako o specifických případech umělecké činnosti, umělecké situace, výjevu či události, je cosi špatně, tvrdil několik desetiletí před Ortegou y Gassetem William Morris: „pokud naše domy, oblečení, nábytek a ostatní nástroje nebudou uměleckými díly, nemohou být než provizorní náhražkou, nebo hůře, ponižující nápodobou luxusních věcí". 4

Zaměříme se nyní především na kontextualistickou stránku Whiteheadových a Deweyho myšlenek o umění, přičemž se pokusíme ukázat, že oba dokázali zjevný konflikt obou těchto pozic řešit, oba dva tak činí podobným způsobem, tj. začleněním obou tendencí do jedné metafyzické hypotézy, a především, navzájem se v tomto ohledu doplňují. V obou zmíněných tendencích, v izolacionistické i kontextualistické, je totiž očividně obsaženo cosi pravdivého. $\mathrm{Na}$ jedné straně je tu předpokládaná autonomie umělecké tvorby, tedy umělecké tvoření jako vytváření zvláštních objektů, jejichž účel nelze beze zbytku podřídit jiným, běžným druhům produkce. Ta nacházela a nadále nachází v izolacionistických vymezeních se proti běžnému, každodennímu či praktickému svo̊j hlavní vysvětlující nástroj. Na straně druhé samozřejmé přijetí této klíčové moderní teze o bezúčelnosti umění od počátku vyvolává nesouhlasné reakce. Pokusíme se ukázat, že Whitehead i Dewey nejen podobným, ale navzájem se doplňujícím způsobem dokázali rozpoznat soudobou problematickou situaci, pro kterou je existence umění řešením, avšak v níž je současně jeho funkčnost ohrožena. Zároveň se budeme snažit doložit, že oba dokázali v rámci svých úvah nad řešením této problematické situace začlenit obě tendence produktivním způsobem.

2 J. Ortega y Gasset, Dehumanizácia umenia, in: J. Ortega y Gasset, Eseje o umení, Archa, Bratislava 1994 (1925), s. 20-21.

3 M. Rader, Isolationist and Contextualist Esthetics: Conflict and Resolution, viz výše, s. 393-394.

4 W. Morris, The Lesser Arts of Life: An Adress Delivered in Support of the Society for the Protection of Ancient Buildings, Electric Book Company 2000 (1882), s. 9. 


\section{Dva významy pojmu umění}

Za výrazného kontextualistu ve výše uvedeném smyslu je považován John Dewey, jehož Umění jako zkušenost začíná prímým poukazem právě na nežádoucí předěl mezi životem a uměním. „Jakmile získá umělecký produkt status klasiky, izoluje se od lidských podmínek, které mu daly vzniknout, a od vlivu, který uplatňuje na žitou zkušenost člověka," piśe Dewey. ${ }^{5}$ Pokud jsou umělecké objekty odděleny od podmínek svého vzniku, výrazně proměňují, či dokonce ztrácejí možnost svého působení. Ve 30. letech minulého století si Dewey všímá tohoto stavu a jeho hlavním záměrem na poli estetiky se stává analýza a náprava této situace cestou vybudování vhodnější teorie o uměleckých dílech.

Dewey upozorňuje na paradox, který se kvůli všeobecnému přijetí takto rozdělené představy o vztahu umění a života, díky, či spiše vinou tisíciletí obdivu a sklánění se před mistrovstvím velkých umělců, jako paradox už ani nejeví. Umělecká díla jsou zcela samozřejmě považována za objekty vysoké hodnoty v rámci života společnosti, specifičnost této hodnoty je však definována skrze protiklad vůči běžným, každodenním zájmům těch, pro které by tato hodnota měla být „hodnotná“.

Nicméně zvážíme-li možnosti, které se nám nabízejí, zjistíme, že narážíme na dvojí nebezpečí. První nebezpečí spočívá v tom, že necháme-li izolacionistickou tendenci naprosto ovládnout pole estetické teorie, narazíme na uvedený rozpor. Autonomie umění je sice zajištěna, ale hodnotu uměleckých děl odvozujeme z jejich naprostého vyvázání ze sféry života těch, kteří jsou měŕítkem této hodnoty. Deweyho slovy, umělecká díla by měla být z tohoto hlediska potřebná na základě jejich odtržení od potřeb a cílů ostatních forem lidského úsilí, útrap a úspěchu. ${ }^{6}$ Spornou zůstane tato hodnota i ve chvíli, kdy budeme ono vyvázání vykládat jako moment vytržení, který nám dá zapomenout na banální, nudnou či strastiplnou každodennost. $V$ takovém prožitku je nepochybně př́tomen pozitivní, osvobozující moment a tyto chvíle hrají v lidském životě důležitou roli. Tímto momentem však obtížně vysvětlíme trvající hodnotu, kterou nacházíme v tom či onom uměleckém díle, tedy hodnotu, která nemizí při našem návratu do žité, často strastiplné reality, ale která se do ní promítá, oživuje ji, či dokonce proměňuje. Navíc některá umělecká díla sice za určitých podmínek mohou plnit onu relaxační funkci, nicméně mnoho dalších typů objektů ji plní lépe, jsou za tímto účelem produkovány a s uměním mají pramálo společného. ${ }^{7}$ Ukazuje se, že intuitivně pochopitelný a teoreticky na mnoho způsobů traktovaný kontrast mezi světem umění a mimouměleckou skutečností či mezi světem zakoušeného uměleckého díla a světem našeho individuálního života, který je základem izolacionistické tendence ve filozofii umění, je třeba vyvážit objasněním jejich vzájemné kontinuity.

Obnovení kontinuity mezi uměleckými díly jako rafinovanými a intenzivními formami zkušenosti a každodenními událostmi tvořícími naší zkušenost je tedy úkol, kterému se podle Deweyho kdokoli, kdo chce psát o filosofii umění či estetické teorii, nemůže

\footnotetext{
J. Dewey, Art as Experience, George Allen and Unwin Ltd., London 1934, s. 3.

Tamtéž, s. 5.

Eskapistickou funkci v rámci životního kontinua nepochybně plní sledování nekonečných televizních seriálů, obsesivní čtení fantasy literatury či hraní počítačových her, jež lze z určitého hlediska považovat za umělecká díla, byt tzv. nízkých žánrů. Nicméně např̀ pravidelnou konzumaci alkoholu, popř̀. jiných substancí, za uměleckou aktivitu zpravidla nepovažujeme, přestože uvolnění a dočasné vytržení z každodenní rutiny poskytují spolehlivě.
} 
vyhnout. ${ }^{8} \mathrm{Na}$ umělecká díla jsme si podle jeho slov zvykli pohlížet s posvátnou úctou jako na vrcholky hor vynořující se $\mathrm{z}$ mraků, tolik vzdálené našim každodenním starostem, že je s nimi už ani nespojujeme. Přesto se vrcholky hor nevznášejí bez opory ve vzduchu, připomíná Dewey, dokonce ani jen tak neleží na zemi, „ony jsou zemí v jednom z jejích nejzjevnějších projevů. Je úkolem těch, kteří se zabývají zkoumáním země, geografư a geologů, učinit tento fakt evidentním v jeho různých implikacích. Teoretik zabývající se krásným uměním má před sebou podobný úkol. "9 Musí ukázat, jakým způsobem a z jakého důvodu umělecká díla vznikají a překračují nadmořskou výšku běžné zkušenosti, aniž by s touto úrovní ztrácela kontakt, aniž by bylo zjevné, jakým způsobem tuto rovinu obohacují, tedy jakým způsobem jsou pro ni hodnotná.

Naplnění takového cíle však podle Deweyho naráží na závažný problém. Estetické teorie a filosofie umění ve 20. století ve svém zkoumání smyslu tvorby a vnímání uměleckých děl velmi často vycházejí z již daného, kanonicky ustaveného souboru uměleckých děl, jakkoli se tento soubor snaží problematizovat. Svou teorii tak budují na základě již rozděleného pole, prostřednictvím nástrojů a evidence, které jsou už před začátkem zkoumání zatíženy či konstruovány prostřednictvím dualismu umění a života. Ten je ale v nereflektované podobě kořenem základního problému, který se kontextualistická teorie snaží odstranit. Dewey navrhuje, že je třeba pozastavit výkon navyklých distinkcí, pozapomenout po nějaký čas na existenci uměleckých děl, odvrátit pohled stranou a zaměřit jej na „obyčejné síly a podmínky naší zkušenosti“, které vinou osvojených, nicméně problematických dualismů ani nepovažujeme za estetické. ${ }^{10}$

Co podle Deweyho uvidíme v těchto obyčejných silách a podmínkách zkušenosti, pokud na moment odložíme dlouhodobě osvojený zvyk kompartmentálního pojímání umění? Deweyho příklady odrážejí realitu americké společnosti 20. a 30. let minulého století, nicméně lze je bez velkých potíží adaptovat na realitu dnešní. Jde o výjevy poutající po způsobu umění vnímavý lidský zrak i sluch, momenty a události, které vzbuzují zájem a skýtají potěšení: „[...] kolem jedoucí požární stříkačku; stroje hloubící obrovské otvory do země, nepatrnou lidskou bytost šplhající po stěně věžáku; muže sedící vysoko ve vzduchu na zavěšených traverzách, házející si do ruda rozpálené šrouby, [...] napjatý půvab hráče baseballu zvedající přítomné publikum. "11

Možná překvapivě, ale je to právě kvalita poutající zrak i sluch pro ni samu, která podle Deweyho spojuje rozkoš hospodyně při obdělávání jejího záhonku či spokojenost hospodáře s posekaným trávníkem s tvorbou a recepcí uměleckých děl. Tedy kvalita vytrhávající, oddělující či izolující nás z kontinua povětšinou rutinně, a tudíž nepozorně vykonávaných činností. Kvalita, která nás v pozitivním slova smyslu vykolejí z předem a pracně nastavených kolejí mechanicky vykonávaných činností a otevře našemu vnímání mnohoznačný dynamický svět kolem nás.

Připomeňme, že nebezpečí všeobecné tendence vtěsnávající duši moderního člověka do nejrůznějších úzce vymezených kolejí si intenzivně uvědomoval i Whitehead. At̉ už je jakákoli hodnota jakkoli závažná, píše ve Vědě a moderním světě (1925), pokud se stává statickou a odmítá přijmout výzvy proměňujícího se prostředí, tzn. výzvy k obno-

8 J. Dewey, Art as Experience, viz výše, s. 3.

9 Tamtéž, s. 3-4.

10 Tamtéž, s. 4.

11 Tamtéž, s. 5. 
vě svého vlastního trvání, stává se „hrozivě monotónni““.12 Duše, říká Whitehead, pak trpí „agoniemi klaustrofobie“, trpí nedostatkem pozitivního narušení této monotónnosti a vyhledává jakoukoli příležitost, která přináší změnu a jejímž prostřednictvím může nalézt uvolnění. ${ }^{13}$ Takové prŕležitosti podle Whiteheada nejsou vyhrazeny pro jakoukoli oblast lidského či nelidského tvoření na úkor jiné. Přicházejí odevšud, prostřednictvím „humoru, vtipu, nevážnosti, hry, spánku a - nade vším - umění. 14

Nyní se v rámci nárysu daného opozicí dvou diskutovaných tendencí - izolacionismu a kontextualismu - dostáváme na dohled druhému nebezpečí. Jestliže na straně izolacionistické tendence hrozí její exces v podobě sporného přisouzení hodnoty, vyvstává na straně absolutizace kontextualistické tendence rovněž závažný problém. Pokud jsou totiž např̀. nadšení diváka přehrabujícího se v hořících polenech v krbu a sledujícího fascinující drama šlehajících plamenů či hravost, a tedy nevážnost našeho běžného vyjadřování ve svém zárodku uměleckou aktivitou, co potom takovou aktivitou není?

Jak vysvětlíme a obhájíme existenci autonomního pole umění, s veškerou sítí institucí, pokud „uměni'“ vždy již existuje všude kolem nás? Jak vysvětlíme u obou filozofů rozdíl mezi Uměním ve smyslu děl „krásného umění“, jejichž existence se, jak víme od Deweyho, stala překážkou naplnění jejich funkce, a uměním, jehož stopy Dewey vidí jak v běžných praktických, tak teoretických činnostech, uměním, které podle Whiteheada přichází odevšud, prostřednictvím „humoru, vtipu, nevážnosti, hry, spánku“, tedy uměním v „tak obecném smyslu slova“, že Whitehead „jen stěží přijímá toto označeni“"?15 Jaký je vztah těchto dvou významů pojmu „umění"?

Viděli jsme, že izolacionistická tendence v estetické teorii směřuje k absolutizaci momentu vytržení, tzn. vydělení se z kontinua každodenní zkušenosti, a k definici umění coby výsostného hájemství takové činnosti, která je na něm založena. Výsledkem jejího vlivu může být umění chápané jako zcela oddělené od zbytku života, a tedy již dříve popsaný hodnotový paradox. Naopak kontextualistická tendence - tedy vyvažování izolacionismu ve výše uvedeném smyslu - přirozeně směřuje ke korekci našich představ o specifičnosti umění, ${ }^{16}$ což může naopak vést $\mathrm{k}$ teoreticky často proklamované snaze o jeho rozplynutí v dosud mimouměleckých činnostech skrze rehabilitaci „uměleckosti“ v praktických, sportovních či obecně kulturních aktivitách - vědě či politice -, a tudíž ke ztrátě distinkce mezi uměleckou a mimouměleckou oblastí. ${ }^{17}$ At’ už takový cíl chá-

2 A. N. Whitehead, Science and the Modern World, Pelican Mentor Books, New York 1948 (1925), s. 202.

3 Tamtéž.

14 Tamtéž (kurziva O. D.).

15 Tamtéž, s. 199-200.

16 Casey Haskins v Deweyho Umění jako zkušenosti obdobně rozlišuje mezi „estetikou“, resp. „mýtem estetiky“ a pojetím umění coby výsostného místa úniku před každodenním životem, v němž dochází ke kantovské „svobodné hře poznávacích mohutnosti“ “vykupující nás z odcizenosti všedních činností, a „esteticismem“, resp. „mýtem esteticismu“, který pohliží na kulturu jako na širokou sít praktik, v nichž jsou zkušenosti obvykle spojované $s$ „krásným uměním“ rozprostřeny a absorbovány napříc mimouměleckou oblastí života. Viz C. Haskins, Dewey’s Art as Experience: The Tension between Aesthetics and Aestheticism, Transactions of the Charles S. Peirce Society, roč. 28, 1992, č. 2, s. 242-243.

17 Jednu z nejdiskutovanějších představ tohoto druhu, založenou na rozpoznání mizející „auratičnosti“ tradičního umění a na naději, kterou z hlediska př́stupnosti umění nabízí „éra technické reprodukovatelnosti“, přináší přibližně ve stejné době, z níž pocházejí Deweyho i Whiteheadovy úvahy, slavná Benjaminova esej „Umělecké dílo ve věku své technické reprodukovatelnosti“. Srov. W. Benjamin, Umělecké dílo ve věku své technické reprodukovatelnosti, in: W. Benjamin, Dílo a jeho zdroj, Odeon, Praha 1979, s. 17-47. 
peme jako nebezpečí nebo jako ideál, k němuž bychom měli jako společnost směřovat, Dewey ani Whitehead naplnění takového cíle nezvažují, oba stále věří v moc onoho „vysokého“ umění a nezatracují jej ve prospěch čehokoli, co by mělo nastoupit na uvolněný piedestal.

Toto rozplynutí je druhým zmíněným nebezpečím. Nemluvíme zde totiž metaforicky, jako když o výjimečně zručném kuchaři či zubaři říkáme, že je „umělcem“ v tom, co dělá, - kontextualistická teze je míněna doslovně. Pokud by se idea všudypř́tomnosti umění beze zbytku naplnila za současného vymýcení jakýchkoli stop izolacionismu, kde potom hledat důvod, proč si vydržovat jednu poměrně nákladnou instituci s její vysoce nákladnou sítí agentů a souvisejících činností, může-li být hodnota, která je důvodem její existence, realizovatelná kdekoli jinde?

Naprosté naplnění kontextualistické ambice, resp. její exces, neústí jako v předchozím př́ípadě v logickém sporu, nýbrž v situaci, v níž umění jako specifická instituce či jako specifický druh produkce mizí, nebo se bude přinejmenším jevit jako zbytečné. Takový stav není vnitřně rozporný, naopak je představitelný a jeho možnost je historicky vykazatelná. V moderní západní společnosti však umělecká díla nevznikají zničehonic, umění jako specifický typ produkce určité hodnoty, stejně jako umělecká díla jako jednotlivé př́ležitosti pro realizaci této hodnoty, nevznikají náhodou či z pouhého rozmaru. Jedná se o záměrně, s určitým očekáváním vytvářené nástroje, které fungují lépe či hưře, byt je jejich funkce ve srovnání s ostatními nástroji zvláštní, jak ji nedávno označil Alva Noë, či podivná. ${ }^{18}$ Jejich podivnost, tzn. skutečnost, že z hlediska jejich účelu je nelze jednoduše zařadit do toho typu účelnosti, který představují běžné praktické či teoretické nástroje, či dokonce že jejich účelnost je běžné účelnosti protikladná, však odkazuje ke specifické, byt poněkud záhadné roli, kterou z hlediska celkového fungování společnosti hrají. Vynořuje se nám tu možnost neexcesivního naplnění kontextualistické tendence, možnost vzájemného propojení obou popisovaných aspektů, kontrastu i kontinuity, obou diskutovaných tendencí, izolacionismu a kontextualismu, a obou uvedených významů umění.

\section{Půda, z níž vyrůstá umění}

Jak již bylo řečeno, Dewey i Whitehead si uvědomovali nebezpečí spočívající v excesivním důrazu na kterýkoli z obou aspektů estetické zkušenosti - kontrast i kontinuitu. Jejich pojetí umělecké tvorby i recepce je proto založeno na hlubší rekonstrukci toho, co všeobecně považujeme za instance krásy, co považujeme za estetické a co tak často a chybně identifikujeme výhradně s tím, co je umělecké. Oba si byli vědomi, že jejich značně široké chápání umělecké aktivity je do určité míry kontraintuitivní. Pokud bychom řekli onomu muži rozdělávajícímu oheň, že při jeho rozdělávání zakoušel uměleckou zkušenost, byt v její zárodečné formě, patrně bude zmaten. ${ }^{19}$ Podle běžného mínění je přece umění cosi, co je zahaleno poklidem - popř. obtížně pochopitelným ruchem výstavních síní, sympozií, workshopů, něčím, co dává ostentativně najevo svou distanci

18 A. Noë, Strange Tools. Art and Human Nature, Hill and Wang, New York 2015.

19 J. Dewey, Art as Experience, viz výše, s. 5. 
vůči běžně vykonávaným činnostem a co má tak málo společného s aktivitou, jako je rozdělávání ohně nebo sekání trávníku.

Vyvstává zde očekávatelná námitka, podle níž není všechno umění hájemstvím sebestředné izolace. Je tu přece množství uměleckých druhů, směrů a tendencí, které již minimálně půlstoletí „performuji“" v rámci „veřejného prostoru“, „intervenuji“ do něj, „navazují s ním dialog“, „provokují jej, aby vyvolaly změnu zažitých stereotypů. Tento poukaz je zcela na místě, je však třeba zdưraznit dvě věci. Za prvé, úsilí o filosofickou rekonstrukci kompartmentálního pojetí umění nepředpokládalo a nepředpokládá, že veškeré umění je odděleno od společnosti, ale mírí právě na určující sílu „běžného míněni“, které stabilizuje normu, podle níž se většinově orientujeme v tom, co je či není umění. Schopnost umění tuto normu aktivně narušovat, posunovat či měnit tím není nijak zpochybněna. Za druhé, zmíněné umělecké aktivity spíše potvrzují, než vyvracejí př́tomnost předělu či intuitivně akceptované hranice mezi světem umění a světem běžného života,

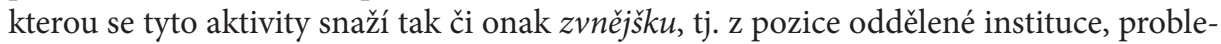
matizovat a aktivně proměňovat, byt jinými prostředky, než které se pokoušejí k témuž využít filosofové. ${ }^{20}$

Nutno připomenout, že naše „běžné míněni“, jímž míníme naše intuitivně přijímané předpoklady, včetně těch týkajících se mimoběžnosti světa umění a světa každodennosti, nejsou z Deweyho ani z Whiteheadova hlediska odrazem jakékoli konečné ontologické diference. Jsou výsledkem dlouhého, historicky založeného procesu, jenž procházel, prochází a s největší pravděpodobností bude procházet dalším vývojem. Neprostupnou bariéru mezi institucí světa umění a mimouměleckým „zbytkem“ našeho života nelze uspokojivým zpo̊sobem odstranit, aniž bychom přijali pragmatický aspekt obou teorií, podle něhož změna zpo̊sobu, jakým o věcech smýšlíme, proměňuje samu povahu věcí. ${ }^{21}$ To neznamená primát druhého před prvním, tedy primát myšlení, resp. teorie před zkušeností. Právě naopak, pro oba filosofy platí, že neexistuje žádná náhrada za postihování věcí v jejich aktualitě. Nicméně zahrnutí maxima toho, co je pro danou zkušenost relevantní, toho, co o ní víme či můžeme vědět, vede ke zpětnému osvětlení cennosti, resp. hodnoty zakoušeného a k prŕpadné proměně horizontu možné zkušenosti. ${ }^{22}$

Podívejme se na Deweyho př́klad. S uměleckými díly tomu podle jeho názoru není jinak než s květinami. Ty mohou být také, jak říká Dewey, vnímány s potěšením, aniž bychom museli pronikat do vzájemných vztahů mezi půdou, ovzduším, vláhou a semeny, z nichž květiny vyrůstají. Pokud však naše pojímání rozšíríme o tyto vztahy, dosáhneme nového porozumění a teorie, dodává Dewey, by měla přinášet porozumění. ${ }^{23}$ Nejinak je tomu s uměním. $Z$ uměleckých děl bychom se měli být schopni těšit bez nezbytných ponorů do sfér a vrstev, které vytvářejí předpoklady jejich vzniku, pokud tedy máme to štěstí a vyrůstáme a žijeme v prostředí, které rozvíjí potřebné předpoklady a disponuje potřebnými prostředky. Požadavek porozumění, které je analogické tomu s květinami,

$20 \mathrm{~V}$ této souvislosti může být zajímavé, že např. Allan Kaprow, jeden ze zakladatelů akčního, performativního umění a hapenningu, právě Johna Deweyho považoval za „duchovního otce“ svých uměleckých snah. Viz A. Kaprow, Essays on the Blurring of Art and Life, Jeff Kelley (ed.), University of California Press, Berkeley 1992, s. xxvi.

21 Srov. např. C. Haskins, Dewey's Art as Experience: The Tension between Aesthetics and Aestheticism, viz výše.

22 A. N. Whitehead, Science and the Modern World, viz výše, s. 199.

23 J. Dewey, Art as Experience, viz výše, s. 12. 
se však stává nezbytným v situaci, v níž umělecká díla přestávají být srozumitelná, aniž bychom jim přestali přisuzovat vysokou hodnotu pro naše životy. Zkoumání životních procesů, které jim původně daly vzniknout, jistá anamnéza současného stavu moderního myšlení, může tuto problematickou situaci vyřešit.

Problematická je tato situace v obou směrech. Jak z hlediska nížiny mimouměleckých estetických jevů, například zmíněných květin, pohlížíme-li k uměleckým výšinám, tak z perspektivy těchto výšin směrem dolů. Neblahý vliv obecně přijímané hranice mezi uměním a životem se projevuje na obou stranách, jak v odcizenosti a esoteričnosti uměleckých výtvorů, tak v banálnosti a marginalizaci mimouměleckých estetických jevů. Jsou-li totiž umělecká díla vyzvednuta do nedostižných výšin, stávají se přirozeně paradigmatickou a vposled určující instancí estetického objektu. S pohledem upřeným k nejvýznačnějším projevům umění potom obtížně zaznamenáváme plíživé přijetí normativních předpokladů identifikujících zdánlivě nehodnotícím, popisným způsobem vše estetické s uměním a vše umělecké s vysokým uměním. Tato postupující izolovanost světa umění, sama o sobě hodnotově paradoxní, má pak zpětný negativní dopad na oblast, od níž se tento svět oddělil, a to nejen ve smyslu opomíjení přírodní krásy, ${ }^{24}$ nýbrž rovněž ve smyslu marginalizace všech druhů estetických výtvorů, které neodpovídají kritériím a nárokům umění vysokého, jako jsou řemesla, běžný design, zahradničení apod. Takováto hodnotová marginalizace a podceňování jejich významu pak nemůže nemít reálný negativní dopad na jejich samotnou existenci a výkon činností s nimi spojený.

Chceme-li dosáhnout nového porozumění uměleckým dílům, usilujeme v Deweyho smyslu zachovat umění jako možnost perspektivy, díky níž rozpoznáváme zdroj a stopy estetična a umění $\mathrm{v}$ běžném životě, $\mathrm{V}$ takovém případě ale musíme vzít nutně $\mathrm{v}$ úvahu „půdu, ovzduší, vláhu a semena“, z nichž umělecká díla vyrůstají. Jak bylo ukázáno výše, na této cestě je třeba se vyhnout jak excesu spočívajícímu v teoretickém zbytnění izolujícího momentu zkušenosti s uměleckými díly, tak excesu rozpuštění distinkce mezi uměním a mimouměleckou oblastí. Je nezbytné přijmout obě tyto tendence společně s intuicí, která za nimi stojí.

Ronald William Hepburn ve své pionýrské studii, zabývající se rehabilitací jedné z opomíjených mimouměleckých oblastí estetična - přírodní krásy -, jejíž vytěsnění lze chápat také jako důsledek výše popisovaných procesů, explicitně upozornil ono nebezpečí spočívající ve zbytnění jak izolacionistického, tak kontextualistického pojímání estetické zkušenosti. Hepburn se zhruba čtyři desetiletí po Deweyho a Whiteheadových úvahách o zdrojích umění v běžné, každodenní zkušenosti pokusil ukázat, že jedním z rozlišujících momentů estetické zkušenosti přírody je moment pohlcení prostředím, v němž se v daný moment nacházíme, přestože tento moment není naprosto cizí ani umění.

Hepburn zdůrazňuje, že vzájemné pohlcení (involvement), splynutí (či fúze, chtělo by se říci s odkazem na Deweyho a Whiteheadovy úvahy) diváka a kontextu, v němž se ocitá, je zároveň vyváženo opačným efektem, kdy divák zakouší sám sebe neobvyklým a pronikavým způsobem a kdy tento rozdíl pouze neregistruje, ale prodlévá u něj, zaskočen bohatostí a nevyčerpatelností takové události. Pokud by jeho studie bývala měla větší

${ }^{24}$ R. W. Hepburn, Contemporary Aesthetics and the Neglect of Natural Beauty, in: R. W. Hepburn, ,Wonder' and Other Essays. Eight Studies in Aesthetics and Neighbouring Fields, Edinburgh University Press, Edinburgh 1984, s. 9-35. 
rozsah, píše sám Hepburn, bylo by třeba „podrobněji se věnovat různým významům ,odstupu'a ,zapojení, které jsou zde relevantní. ${ }^{25}$ A právě specifický, komplementární vztah odstupu a zapojení nalezneme se znatelným předstihem v konvergentních liniích Deweyho a Whiteheadova myšlení.

\section{Skryté dějiny mravů}

Jak se tedy děje to, že z běžného vytváření věcí, z každodenních činností, z obyčejného dění vzejde něco, co je v původním slova smyslu umělecké? Co tvoří linii kontinuity mezi radostí z každodenních výjevů a situací a „zvláštním uspokojením, které doprovází zkušenost bezpochyby estetickou“?26 Podívejme se nejprve, jaké podmínky či faktory podle Deweyho a Whiteheada žádoucí prostupnosti života a umění brání. Dospějeme tak k uchopení překryvu obou metafyzických hypotéz efektivněji, než kdybychom se snažili představit organické začlenění umění v životním proudu u každé zvlášt.

Dewey si klade otázku, odkud se bere náš odpor, nebo přinejmenším pocit nepatřičnosti, zakoušený při spojování vyšších, ideálních předmětů možné zkušenosti s jejich vyživujícími kořeny nacházejícími se v tom, co je běžné, obyčejné, materiální či tělesné. Proč pocitujeme jako zpronevěření se vyšším hodnotám, jestliže klademe výtvory krásných umění do souvislosti s běžným životem, tedy „životem, který sdílíme se všemi žijícími bytostmi“?27 Odpověd’ na otázku, proč se běžná fyzická interakce se světem stala místem nízkých žádostí a hrubé smyslovosti, by podle Deweyho předpokládala sepsání takových dějin mravů, které odhalí ono hluboké zafixování všeobecného a hlavně chybného „opovržení vůči všemu tělesnému, strachu před smysly a opozice těla a ducha“ ${ }^{28}$

Život společnosti, včetně toho institucionálního, je podle Deweyho neustále probíhajícím proudem transakcí či interakcí různé úrovně a komplexity. Toto zčásti uspořádané, zčásti své uspořádání neustále hledající dění je však zakryto či zamaskováno statickým rastrem oddělujícím jednotlivé sféry politiky, náboženství, obchodu a mezi dalšími i umění. Tato rozlišení jsou nepochybně výsledkem živých, dynamických procesů, problém však spočívá v tom, že tento organicky vzniklý vzorec je z tohoto dění vyňat, je abstrahován a následně mechanicky, tj. bez ohledu na původní procesy, do původního dění projektován. Abstrahované distinkce mezi jednotlivými hodnotovými poli jsou obratem považovány za cosi, co je skutečnější než ona dějící se skutečnost, co je dokonce považováno za její konečný, ontologický či metafyzický základ.

Předmět Deweyho kritiky je prrípadem obecnější tendence, kterou Whitehead nazývá „klamem chybně situované konkrétnosti“. ${ }^{29}$ Tento omyl má podle Whiteheada mnoho vrstev a projevů, nicméně vždy spočívá v záměně, během níž jsou původní, mnohoznačné, konkrétní fakty nahrazeny velmi abstraktními logickými konstrukcemi, jimž daly vzniknout. Chyba nespočívá v samotném vytváření těchto abstrahovaných plánů skutečnosti, ty mají být a jsou zpravidla čímsi velmi užitečným, chyba spočívá v tom, že

25 Tamtéž, s. 13.

26 J. Dewey, Art as Experience, viz výše, s. 12.

27 Tamtéž, s. 20.

28 Tamtéž.

29 A. N. Whitehead, Science and the Modern World, viz výše, s. 52. 
je pro jejich efektivitu považujeme za skutečnější než onu mnohotvárnou, dynamickou skutečnost, z níž vzešly.

Jinými slovy, pro naši orientaci je užitečné vytvořit si mapu určitého území s jednotlivými okrsky, centry a hranicemi rozlišitelných druhů terénu. Z téhož důvodu je užitečné vytvořit si „mapu“ institucionálního uspořádání určité společnosti s jeho centry, rozlišit hodnoty, které tvoří společnou bázi a důvod existence jednotlivých hodnotových polí, včetně institucí, jež na této bázi vznikají. Avšak považovat tyto abstrahované distinkce obratem za určující a neměnný základ živé skutečnosti je stejně smysluplné jako považovat mapu za určující a neměnný základ území, jehož je vyjádřením. ${ }^{30}$

Myšlenky obou filosofů se zde - obdobně jako na dalších místech - nepotkávají náhodou. Obdobný vhled do postupného rozpadu společného světa a konstituce oddělených polí zájmů a činností vede mnohem hlouběji. Jestliže Dewey uvažuje o nutnosti sepsání dějin mravů, jež by popsaly postupné přijetí dualismu těla a mysli, činí tak proto, že naráží na negativní důsledky, které tento ústř̌ední předpoklad moderního myšlení měl a nadále má, na „rozškatulkované“ (kompartmentalizované) prostředí života moderní společnosti.

Rozlišení jednotlivých činností a zájmů, které sledují, je totiž navázáno, poznamenává Dewey, na hlouběji založenou distinkci, jejíž vinou zdánlivě přirozeně rozlišujeme mezi „vyššími“ a „nižšími“ činnostmi, mezi porozuměním a praxí, mezi imaginací a (pouhým) provedením, povoláním a (pouhou) prací, mezi (pouhou) emocí a myšlením či konáním. ${ }^{31} \mathrm{O}$ všech těchto rozlišeních se obvykle domníváme, že kopírují neměnný půdorys, na jehož základě je konstituována lidská přirozenost, ona stavba vyšších (duševních) a nižších (tělesných, smyslových) schopností.

Podle Deweyho je tato degradace určitých oblastí a činností v rámci současného ekonomického a institucionálního nastavení silná natolik, že smyslům odmítáme přiznat schopnost realizovat jakoukoli vnitřní hodnotu a zcela bez rozpaků je pokládáme za pouhé prostředníky vyšších hodnot nebo zdroj nízkých požitků:

Smyslové vjemy zakoušíme jako [pouhé] mechanické stimuly či jako otravná vyrušení, bez významu skutečnosti, který je v nich a za nimi obsažen: $\mathrm{v}$ mnohých z našich zkušeností se smysly nesjednocují, aby vyprávěly společný rozsáhlejší příběh. Vidíme bez pocitu, slyšíme, ale jen zprávu z druhé ruky, z druhé proto, že není posílena viděním (vision). Dotýkáme se, ale náš dotyk zůstává letmý, protože se nespojuje se smysly, které pronikají pod povrch. Používáme smysly k povzbuzení vášně, nikoli však k naplnění zájmu porozumění (insight). Není tomu tak kvůli tomu, že [tento] zájem by nebyl ve výkonu smyslů přítomen, nýbrž proto, že se podřizujeme [těm] podmínkám života, které nutí smysl, aby zůstal pouhým povrchovým vzrušením. Prestiž následuje ty, kteří používají mysl bez použití těla, kdo jednají skrze ovládání těl a práce druhých. ${ }^{32}$

Stačí letmé přezkoumání současného stavu věcí, abychom shledali, že Deweyho slova neztrácejí na platnosti. Možná ještě více než před sto lety, ze stejných a z mnoha dalších, nových důvodů, stále vidíme a slyšíme bez pocitu, byt v kritice této degradace smyslového

30 Př́iklad Johna Cobba, srov. J. B. Cobb, Jr., Whitehead Word Book: A Glossary with Alphabetical Index to Technical Terms in Process and Reality, P\&F Press, Claremont 2008, s. 15-16.

31 J. Dewey, Art as Experience, viz výše, s. 21.

32 Tamtéž. 
bylo v průběhu 20. století vykonáno mnohé. Přesto stále prestiž následuje spíše ty, kteří pracují hlavou a využívají tělesné práce druhých. Vyvstávají před námi dvě otázky, jejichž zodpovězení zakládá možnost $\mathrm{z}$ jednoho bodu nahlédnout výše diskutované uchopení kontrastu i diskontinuity, odstupu i zapojení, a konečně obou významů umění: Jak moderní společnost dospěla do tohoto stavu a jaké prostředky se jí nabízejí k jeho nápravě?

Dewey v polovině 30. let oprávněně zmiňuje potřebu sepsání takových dějin mravů, v nichž by se ukázalo zrození a postupné všeobecné přijetí zdánlivě samozřejmého opovržení vůči všemu tělesnému, opatrnosti či strachu před smysly, dualismu těla a ducha. Jednotlivé kapitoly takovýchto dějin můžeme od té doby hledat v dílech mnoha filosofư 20. století, nicméně již ve 20. letech lokalizuje klíčový moment těchto dějin Alfred North Whitehead v prvním ze tří základních děl svého metafyzického období, v již citovaném spise Věda a moderní svět.

Whitehead zde předkládá široký dějinný oblouk, který zahrnuje historické a konceptuální předpoklady vynoření se moderní vědy v 17. a 18. století, a dále zpưsob, jakým tento proces v 19. století - v dobrém i ve zlém - proniká všemi vrstvami života společnosti a zasahuje i ty nejsamozřejmější a nejniternější předpoklady našeho myšlení a vnímání. Toto všeobecné pojetí, rámcový prrístup ke světu, který věda podle Whiteheada vnesla do moderního myšlení, nelze oddělit od filosofické situace, jak byla formulována v díle Reného Descartesa. Whitehead má na mysli zásadní prosazení se předpokladu na sobě nezávislých těl a myslí, jež jsou následně stále více a do stále větší hloubky pojímány jako nezávislé individuální substance. Whitehead připomíná, že se nejedná o cosi radikálně nového, co by nijak nesouviselo s aspekty předchozích věků a jejich epistemologických konfigurací. Naopak, tento moderní dualismus navazuje na individualismus, který vyplývá z mravního učení středověku a jemu vlastních předpokladů týkajících se vztahu duchovní sféry a tělesnosti. ${ }^{33}$

$\mathrm{Na}$ jedné straně můžeme podle Whiteheada touto cestou pochopit kontinuitu obou epoch, na straně druhé je třeba na pozadí této kontinuity identifikovat určité zmatení, „které je přirozené, nikoli však o to méně neštastné “ ${ }^{34}$ Mravní řád obsažený v křestanském učení zdůrazňoval vnitřní hodnotu individuálního jsoucna, avšak v přechodu mezi středověkým pojetím a vynořující se moderní dobou můžeme, zdůrazňuje Whitehead, zaznamenat proměnu individuální hodnoty každého individua v nezávislou substanciální existenci. ${ }^{35}$

Jak dochází k této radikální, byt’ vinou zmíněné návaznosti obtížně pozorovatelné proměně pojetí „vnitřní hodnoty“ individuálního jsoucna? Descartes podle Whiteheada neučinil záměnu v podobě explicitní úvahy, toto nahrazení probíhá takřka mimoděk. Descartes se nejdříve zaměřuje na své vlastní vědomé prožitky, analyzuje je jako fakty v izolovaném, soběstačném světě svého myšlení. Takováto spekulace by podle Whiteheada byla těžko představitelná bez zděděného důrazu na hodnotu individuálního já. Nicméně děje se zde takřka nepozorovatelné uzavření oné individuální hodnoty každého jedince, která je bezpochyby vykazatelná na půdě vlastní zkušenosti, v „privátním světě vášní či modů nezávislé substance“ ${ }^{36}$ Tento předěl a na něm založená nezávislost přisou-

33 A. N. Whitehead, Science and the Modern World, viz výše, s. 194.

34 Tamtéž.

35 Tamtéž.

36 Tamtéž. 
zená tělesným substancím je prvním krokem na cestě k úplnému odloučení tělesného, smyslového a materiálního od sféry hodnot.

Svět přírody, země i nebesa tak pozbyly Boží slávy, píše Whitehead, a degenerovaly ve zcela bezhodnotový mechanismus, který mohl jakoukoli vnější tvořivou sílu nanejvýš připomínat. Jak již bylo řečeno, nadřazování duševního nad tělesným, spirituálního nad materiálním, bylo v západním myšlení přítomno již před Descartesem. Nicméně byla to moderní věda, které pomohli ke zrození racionalisté v čele právě s Descartesem, která dala stabilitu a intelektuální status ryze modernímu hledisku. Whitehead nezapomíná zdůrazňovat, že tento posun nebyl ničím vynuceným, nebot byl živen pozitivními dopady, mezi něž patřila především efektivita nových metod vědeckého zkoumání. Očištění evropské mysli „od stop zanechaných hysterií vzdálených barbarských věkü“ otevřelo netušené a nedozírné možnosti, které se projevily v rapidním rozvoji technologie a průmyslu následujících dvou století. Tento proces měl však také, jak Whitehead rovněž nezapomíná kontinuálně připomínat, svou odvrácenou stranu. ${ }^{37}$

Mezi tyto negativní důsledky předpokladu čisté bezhodnotovosti pouhé hmoty patří podle Whiteheada „absence ohledu v pojímání prírodní a umělecké krásy“.38 $\mathrm{V}$ průběhu 19. století se začala razantně rozvíjet urbanizace a industrializace západního světa. V této době, v níž by bývalo bylo nanejvýš potřebné, jak zdůrazňuje Whitehead, co nejjemněji a nejcitlivěji nakládat s estetickými kvalitami nového materiálního prostředí, byla na vrcholu doktrína, podle níž jsou tyto ideje a tyto hodnoty vzhledem k materiálnímu, každodennímu světu zcela irelevantní. „V nejrozvinutějších průmyslových zemích bylo umění pojímáno jako něco frivolního. Do očí bijícím příkladem tohoto stavu mysli je v polovině 19. století Londýn, kde byla úžasná krása ústí Temže vinoucí se městem bezohledně znetvořena železničním mostem Charing Cross, postaveným bez ohledu k estetickým hodnotám, “ dodává Whitehead. ${ }^{39}$ Je zřejmé, že Whitehead si obdobně jako Dewey uvědomoval skutečnost, že oblast estetických hodnot a idejí se oddělila od běžného, již bezhodnotově pojímaného světa našich životů. Stejně jako Dewey nacházel jednu ze základních příčin hluboko $\mathrm{v}$ dualistických předpokladech moderního myšlení, a jak si v závěru ukážeme, obdobně jako Dewey o deset let později nacházel v tomto stavu dvě základní zla: „za prvé, ignorování pravdivého vztahu mezi každým organismem a jeho prostředím; a za druhé, zvyk ignorování vnitřní ceny prostředí, jíž musí být přiznána závažnost při jakémkoli uvažování konečných cílů. “40

Podobně jako Dewey rozpoznává i Whitehead související a výše uvedenými podmínkami vytvořenou situaci, $v$ níž vzniká potřeba vychovávat úzce zaměřené, „rozškatulkované“ profese, specializované na jednotlivé oblasti praktických i teoretických činností. Tato kompartmentalizace má opět svou kladnou stránku, uvnitř omezených hranic svého předmětu dosahuje bádání a aplikace jeho výsledků nebývalé efektivity. „Efektivní poznání,“ píše Whitehead, „je profesionalizované poznání, podporované omezeným osvojením si témat, která lze v tomto směru využít. " 41 Nicméně opět doplňuje i druhou stranu:

\footnotetext{
37 Tamtéž, s. 195.

38 Tamtéž.

39 Tamtéž.

40 Tamtéž, s. 196.

41 Tamtéž.
} 
Tato situace má svá nebezpečí. Produkuje mysli ve vyjeté stopě (groove). Každá profese prochází vývojem, jedná se však o vývoj ve vyjetých, předem daných kolejích. Rutinně myslet znamená žít v rámci uvažování daném [určitým] souborem abstrakcí. Rutina (groove) zabraňuje vykolejení a abstrakce abstrahuje od něčeho, čemu dále není věnována žádná pozornost. Neexistuje však žádná rutinnost abstrakcí, která by byla adekvátní pochopení lidského života. V moderním životě byl tedy celibát středověké učené třídy nahrazen celibátem intelektu, jenž je oddělen od konkrétní kontemplace úplných faktů. Samozřejmě, nikdo není pouze matematik nebo pouze právník. Lidé mají své životy mimo své profese či své obchody. Věc však spočívá v ústupu vážného myšlení do určitých kolejí. Zbytek života je uvažován povrchně, s nevyvinutými kategoriemi myšlení odvozenými $\mathrm{z}$ jedné profese. ${ }^{42}$

Jak je vidět, Whitehead odhaluje základní nebezpečí způsobem, který vychází přímo vstříc Deweyho diagnóze soudobé situace umění. Za prvé, tato situace je přednastavena všeobecně přijatým dualistickým náhledem, který ústí v degradaci těla a smyslů a v bezhodnotové pojetí hmoty. Za druhé, jak ukazuje právě uvedený úryvek, zvyšující se efektivita moderní parcelace činností a jim příslušných oblastí hodnot vede k jejich silně kompartmentálnímu, mimoběžnému, do sebe uzavřenému pojetí. Dewey ze stejných důvodů, avšak v opačném směru, upozorňuje na takřka nutnou konsekvenci tohoto procesu. Je totiž těžko představitelné, že by se umění mohlo ubránit tomuto vlivu, oddělujícímu jednotlivé sféry politiky, náboženství, obchodu a vědy, a neskončit tak nakonec v odděleném, izolovaném „světě“ umění.

\section{Umění a nežádoucí podmínky růstu}

Jestliže v odpovědi na první položenou otázku - jak moderní společnost dospěla do popisovaného stavu - nacházíme u Whiteheada a Deweyho základní shodu, zbývá zvážit jejich postoj k otázce druhé, tj. jaké prostředky se nabízejí k jeho nápravě. Podle Whiteheada je „moudrost ovocem vyváženého vývoje“.43 Co to je ale „vyvážený vývoj“ a v čem spočívá? Whitehead má vyváženým vývojem na mysli vyrovnaný růst jedince, který je založen na vzájemném vyvažování dvou složek. Ta první zahrnuje potřebné rozvíjení výše kritizovaného profesionalismu, které se neobejde bez analytického oddělení se jedince od jeho prostředí, bez soustředění se na soubor abstrakcí vlastní příslušnému oboru. ${ }^{44}$

Tuto složku je však podle Whiteheada nutno vyrovnávat rozvíjením intuice „bez analytického oddělení od celkového prostředí. Tato intuice znamená podle Whiteheada „bezprostřední pojímání s minimem omezující analýzy“. ${ }^{45}$ Takové vnímání nesměřuje pouze k ocenění partikulárních, konkrétních faktů, ale skrze ně k uvědomění si vzájemné souvztažnosti a různosti hodnot:

Mám tím na mysli možnost estetického růstu (aesthetic growth). Existuje něco mezi hrubými, specializovanými hodnotami praktického člověka a úzce specializovanými

\footnotetext{
42 Tamtéž, s. 196-197.

43 Tamtéž, s. 197.

44 Tamtéž.

45 Tamtéž, s. 199.
} 
hodnotami pouhého učence. Oba typy o něco přicházejí, a pokud tyto soubory hodnot dáte dohromady, nedostanete to, o co přicházíte. Co schází, je ocenění nekonečné různorodosti živých hodnot dosažených organismem v jeho náležitém prostředí. Pokud plně porozumíte slunci, atmosfére a otáčení země, stále můžete přicházet o oslnivost západu slunce. Neexistuje žádná náhrada za př́mé postihování završení věci v její aktualitě. Vyžadujeme konkrétní fakt s jasným osvětlením toho, co je relevantní pro jejich cennost. ${ }^{46}$

K zajištění „estetického růstu“ by mělo podle Whiteheada přispět „umění a estetická výchova“ ${ }^{47}$ Co je zde míněno těmito vinou častého užívání skoro prázdnými pojmy? O jakou výchovu a umění se zde jedná? Whiteheadovi jde v prvé řadě o výchovu ve smyslu „oživení zvyku estetického pojímáni“' ${ }^{48}$ Uměním je pak v tomto případě míněn onen široký význam, který prostupuje náš každodenní život, umění, které přichází odevšud, prostřednictvím „humoru, vtipu, nevážnosti, hry, spánku““49 Cílem oživení zvyku estetického pojímání (apprehension) je co nejširší prohlubování otevřenosti individua vưči jedinečnosti vnímaného. „Uměni“" v tomto smyslu znamená podle Whiteheada „jakýkoli výběr (selection), jímž jsou konkrétní fakty uspořádány takovým způsobem, že osvětlují pozornost k určitým hodnotám, které jsou jimi uskutečněny. Například pouhá poloha lidského těla a výhled, který tím zaujmeme, abychom se mohli těšit západem slunce, jsou jednoduchými formami uměleckého výběru“. ${ }^{50}$ Oživení tohoto zvyku znamená paradoxní oživení zvyku jakýkoli zvyk prvního řádu pozitivně narušovat, tedy umění vykolejit se ze zajetých kolejí.

Co však v tuto chvíli s oním „vysokým uměním“, které je, jak píše Whitehead, nad oním širokopásmovým uměním ve smyslu jakéhokoli pozitivního narušování zvyku? Vyjěme nyní z druhé strany, od Deweyho konvergentních úvah o vztahu umění k navyklým trajektoriím našeho života:

Skrze zvyky (habits) vytvořené na základě kontaktu se světem tento svět obýváme (in-habit). Stává se naším domovem a domov je součástí každé naší zkušenosti.

Jak by potom objekty zkušenosti mohly nebýt expresivními? Přesto apatie a strnulost potlačují expresivitu tím, že objekty uzavírají do určité slupky (shell). Obeznámenost vyvolává nezájem, předsudky nás oslepují; domýšlivost se dívá na svět opačným koncem dalekohledu a minimalizuje tak význam objektů ve prospěch domnělého já. Umění strhává tuto krustu pokrývající expresivitu zakoušených věcí; vybízí nás, abychom vykročili $\mathrm{z}$ ochablosti rutiny, a umožňuje nám zapomenout na sebe a zároveň sebe nalézt v radosti ze zakoušení světa kolem nás v rozmanitosti jeho kvalit a forem. Zachycuje každý odstín expresivity, kterou lze v objektech najít, a uspořádává ji v novou zkušenost života. ${ }^{51}$

Jak již víme, hlavním cílem Deweyho knihy je znovuobjevení původního smyslu umění, resp. zkušenosti s uměleckými díly, který spočívá právě ve „strhávání těchto slupek, které zakrývají expresivitu objektů zkušenosti“. ${ }^{52} \mathrm{~V}$ Deweyho případě je jedním ze zá-

46 Tamtéž.

47 Tamtéž, s. 199-200.

48 Tamtéž.

49 Tamtéž, s. 202.

50 Tamtéž, s. 199-200.

51 J. Dewey, Art as Experience, viz výše, s. 104.

52 Tamtéž. 
kladních náhledů, stejně jako $v$ př́padě předchozím, skutečnost, že habituace, tj. opakovaná úspěšná interakce mezi organismem a prostředím, znamená na jedné straně možnost obývání světa, která vytváří ze světa, v němž se ocitáme, náš domov. Na druhé straně však zvyk tím, jak se stává mechanickým, automatickým, postupně pokrývá předměty naší zkušenosti onou slupkou a snižuje tak uvědomování si nejen primárně kvalitativní povahy našeho kontaktu se světem, nýbrž i vědomí tohoto světa a našeho místa $v$ něm. O jakém umění tu však Dewey mluví? O „vysokém umění, které ční nade vším, nebo o onom „umění, které lze objevit v běžných projevech života kolem nás? Dewey v této pasáži hovoří, na rozdíl od té Whiteheadovy, o „vysokém umění, tedy o umění, jež bylo v situaci, do níž se dostala moderní společnost, zablokováno ve svém vlastním, uzavřeném světě a tím zbaveno své účinnosti.

Pokusili jsme se ukázat, že Whitehead i Dewey se ve výsledcích svých analýz této problematické situace shodují. Zatímco Whitehead proniká hlouběji k jejím historickým prríčinám, Dewey podrobněji analyzuje konstelaci, $v$ níž se na tomto společně nahliženém základě nachází právě „vysoké umění“. Oba, Whitehead i Dewey, však nacházejí možnost řešení této problematické situace v rozpoznání druhého, širšího významu „umění, významu, který prostupuje naši každodennost a jehož rozpoznání a rozvíjení může napravit škody plynoucí z př́lišného důrazu na specializované pojetí výchovy, jak uvádí Whitehead, nebo pomoci překonat bariéru mezi světem vysokého umění a světem každodennosti, jak by si přál Dewey.

Jak píše Whitehead, lidské bytosti totiž potřebují něco, co je na nějaký čas pohltí, cosi, co je vytrhne z rutiny každodenního pohybu ve vyjetých stopách, co je izoluje od omezujícího dění, jež se v těchto stopách odehrává, a co je zároveň pohltí, co otevře jejich vnímání nevyčerpatelnému a mnohoznačnému okolnímu světu. Velké umění nemá být pouhým přechodným vytržením či osvěžením, dodává Whitehead. Jak takřka stejnými slovy uvádí Dewey, velké umění nám pomáhá vykročit z ochablosti rutiny, umožňuje nám „zapomenout na sebe“ a zároveň „sebe nalézt v radosti ze zakoušení světa kolem nás v rozmanitosti jeho kvalit a forem“. Izolaci na jedné rovině následuje o to vyšší míra participace na rovině druhé. Aby však tento kontrast mohl plnit svou funkci, tj. nabízet nejrozvinutější možnost „vykolejeni“" a rekonstrukce našich vlastních já, musí být znovuobnoveno vědomí kontinuity, v jejímž rámci tuto funkci vykonává. A k tomu poslednímu nepochybně přispěla a nadále může přispívat kontextualistická stránka myšlení obou diskutovaných filosofů, založená na vztahu dvou významů pojmu „umění“.

\section{Poděkování}

Za cenné připomínky a návrhy bych rád poděkoval Martinu Kaplickému, Josefu Šebkovi a oběma recenzentům této studie. Text vznikl za podpory grantového projektu GA16-13208S Proces a estetika: explicitní a implikovaná estetika v procesuální filozofii Alfreda North Whiteheada. 


\section{LITERATURA}

Benjamin, W., Umělecké dílo ve věku své technické reprodukovatelnosti, in: Benjamin, W., Dílo a jeho $z d r o j$, Odeon, Praha 1979, s. 17-47.

Cobb, Jr., J. B., Whitehead Word Book: A Glossary with Alphabetical Index to Technical Terms in Process and Reality, P\&F Press, Claremont 2008.

Dewey, J., Art as Experience, George Allen and Unwin Ltd., London 1934.

Haskins, C., Dewey's Art as Experience: The Tension between Aesthetics and Aestheticism, Transactions of the Charles S. Peirce Society, roč. 28, 1992, č. 2, s. 217-259.

Hepburn, R. W., Contemporary Aesthetics and the Neglect of Natural Beauty, in: Hepburn, R. W., ,Wonder' and Other Essays. Eight Studies in Aesthetics and Neighbouring Fields, Edinburgh University Press, Edinburgh 1984, s. 9-35.

Kaprow, A., Essays on the Blurring of Art and Life, J. Kelley (ed.), University of California Press, Berkeley 1992.

Morris, W., The Lesser Arts of Life: An Adress Delivered in Support of the Society for the Protection of Ancient Buildings, Electric Book Company 2000.

Noë, A., Strange Tools: Art and Human Nature, Hill and Wang, New York 2015.

Ortega y Gasset, J., Dehumanizácia umenia, in: Ortega y Gasset, J., Eseje o umení, Bratislava, Archa 1994.

Rader, M., Isolationist and Contextualist Esthetics: Conflict and Resolution, The Journal of Philosophy, roč. 44, 1947, č. 15, s. 393-407.

Whitehead, A. N., Science and the Modern World, Pelican Mentor Books, New York 1948. 